\title{
Exchange Rate Assessment for Sub-Saharan Economies
}

\author{
Burcu Aydın
}




\title{
IMF Working Paper
}

\author{
African Department \\ Exchange Rate Assessment for Sub-Saharan Economies \\ Prepared by Burcu Aydın ${ }^{1}$ \\ Authorized for distribution by Vitaliy Kramarenko
}

July 2010

\begin{abstract}

\section{This Working Paper should not be reported as representing the views of the IMF.}

The views expressed in this Working Paper are those of the author(s) and do not necessarily represent those of the IMF or IMF policy. Working Papers describe research in progress by the author(s) and are published to elicit comments and to further debate.

This paper provides an exchange rate assessment for sub-Saharan African economies by using methodologies similar to those developed by the International Monetary Fund's Consultative Group on Exchange Rate Issues. As in the World Economic Outlook (IMF, 2009a), the unbalanced panel dataset covers 182 countries from 1973 to 2014. We apply four methodologies to assess the fundamental exchange rate: macroeconomic balance, equilibrium real exchange rate, external sustainability, and purchasing power parity. Results show that the impact of macroeconomic fundamentals on the equilibrium real exchange rate is different for sub-Saharan African economies than for advanced and less advanced economies.

JEL Classification Numbers: C23, E3, F31

Keywords: Exchange Rate; Panel Data; Africa

Author's E-Mail Address:BAydin@imf.org

\footnotetext{
${ }^{1}$ I am greatly thankful to Vitaliy Kramarenko for his valuable comments and suggestions. Also, the exchange rate assessment tool-box created by the IMF Strategy, Policy and Review Department was extremely helpful to the analysis used here.
} 
I. Introduction

II. Data

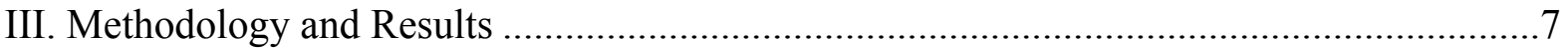

A. Macroeconomic Balance Approach ............................................................

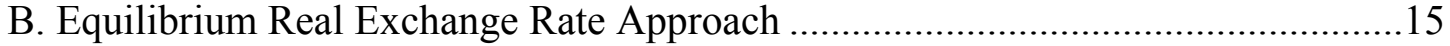

C. External Sustainability Approach....................................................................20

D. Purchasing Power Parity Approach ...................................................................22

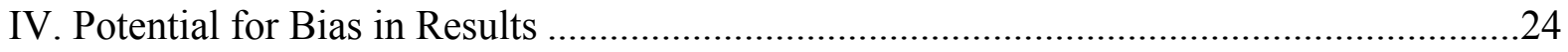

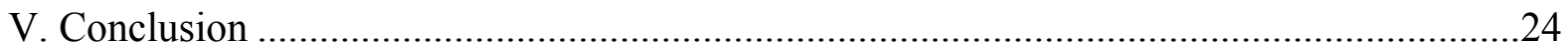

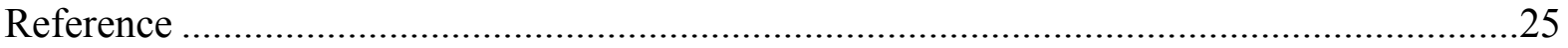

Appendix

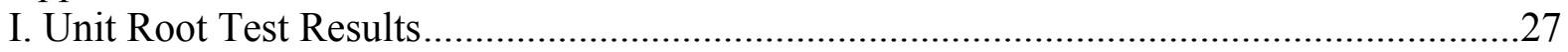

Tables

1. Summary Statistics Across Geographic and Economic Regions, 1973-2008....................6

2. Macroeconomic Balance Estimation Results (Dependent Variable: CAB/GDP) ..............10

3. Macroeconomic Balance Assessment of Sub-Saharan Africa..........................................12

4. Macroeconomic Balance Estimation Results with Nonoverlapping Four-year-Averages ..14

5. Equilibrium Real Exchange Rate Estimation Results..................................................17

6. Equilibrium Real Exchange Rate Estimation Results Controlling for Armed Conflict

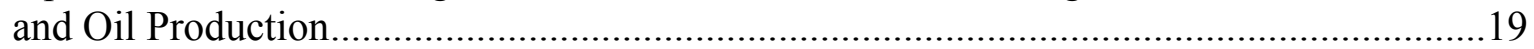

7. External Sustainability Assessment of Sub-Saharan Africa ........................................21

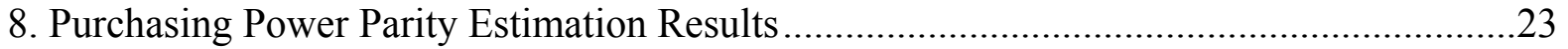

9. Panel Unit Root Test Result for Real Exchange Rate.................................................27

10. Panel Unit Root Test Results for Current Account Balance............................................27

11. Panel Unit Root Test Result for Relative Income per Capita ........................................28

12. Panel Unit Root Test Results for Relative Fiscal Balance.........................................28

13. Panel Unit Root Test Result for Relative Population Growth ......................................29

14. Panel Unit Root Test Result for Relative Economic Growth ........................................29

15. Panel Unit Root Test Result for Initial Net Foreign Assets............................................30

16. Panel Unit Root Test Result for Terms of Trade ............................................................30

17. Panel Unit Root Test Result for Oil Trade Balance.................................................... 31

18. Panel Unit Root Test Result for Relative Dependency Ratio ........................................31

19. Panel Unit Root Test Result for Aid .........................................................................32

20. Panel Unit Root Test Result for Remittance.............................................................. 32 


\section{INTRODUCTION}

Assessments of exchange rate levels are at the core of International Monetary Fund surveillance. Though there have been a number of papers and approaches on conducting such assessments, such as the Consultative Group on Exchange Rates (CGER) study of 54 countries, Vitek (2009) on all the countries covered by the October 2009 World Economic Outlook (WEO; IMF, 2009a), and Christiansen et al. (2009) on selected low-income countries, there has been no research specific to sub-Saharan Africa.

This paper applies four methodologies to evaluate exchange rate levels in sub-Saharan countries in terms of their fundamentals. First is the macroeconomic balance approach, which assesses the exchange rate by evaluating any gap between the current account balance and its norm based on the country's macroeconomic fundamentals. In this methodology, the degree of exchange rate under- or overvaluation is determined by the magnitude of the gap and the elasticity of the current account with respect to the real exchange rate.

Second is the equilibrium real exchange rate approach, which calculates the equilibrium real exchange rate based on the country's macroeconomic fundamentals. The magnitude of under- or overvaluation is calculated as percentage deviation of the observed real exchange rate from its equilibrium value.

Next, the external sustainability approach calculates the norm current account balance which would stabilize the net foreign assets of a country. As with the first methodology, the degree of under- or overvaluation is determined by the magnitude of the gap between underlying and norm current account balances and the elasticity of the current account balance with respect to the real exchange rate.

Finally, the purchasing power parity approach calculates the equilibrium real exchange rate based on the law of one price. Like the equilibrium real exchange rate approach, the sign and the magnitude of the gap between the equilibrium and the underlying level of exchange rate shows the sign and the size of exchange rate under- or overvaluation.

The first three methodologies are similar to those applied by the CGER ${ }^{2}$ except for the number of countries in the dataset, the econometric model, and some of the variables used:

- The dataset in this paper covers all 182 countries that the WEO reported on, including those in sub-Saharan Africa. Among the 54 economies covered by the CGER analysis, no country in sub-Saharan Africa except South Africa is included. Both datasets are unbalanced, and the earliest available data start from 1973; however, the estimation period sample extents to 2008 in this paper, unlike 2004 in the CGER.

\footnotetext{
${ }^{2}$ Lee et al. (2008).
} 
- As for econometric techniques, the CGER uses pooled and fixed effects panel estimation models, and this paper, following Vitek (2009), uses pooled generalized method of moments methodology.

- Even though this paper uses many of the same variables as the CGER, the set-up and choice of some variables differ. The CGER methodology creates variables by taking four-year averages; in this paper, because the time series available for many of the non-CGER countries is shorter, annual data are used. Finally, following Vitek (2009) and Christiansen et al. (2009), here we add aid and remittance as additional variables because of their importance in sub-Saharan Africa.

Because certain economic conditions are unique to sub-Saharan and low-income countries, the econometric estimates were undertaken for several subsamples of countries. First we deal with the whole sample, using all information available, then with a group of low and middle income countries (LMIC), and next with the group of sub-Saharan economies. Finally, among the last, we create a subset by excluding oil-exporting countries.

The results for sub-Saharan Africa have different slope coefficients than those for advanced and LMIC. The impact of macroeconomic fundamentals is different in an equilibrium relationship in sub-Saharan Africa. For instance, the macroeconomic balance approach indicates that the fiscal accounts have about a one-to-one impact on the external balance of these countries, but the impact is much smaller in other LMIC.

In what follows, Section II introduces the data and Section III presents the models used and the results based on these models. Section IV raises some caveats related to the methodologies; and Section V draws conclusions.

\section{DATA}

The dataset for this paper is drawn from annual data for 182 economies from 1973 through 2014. Macroeconomic variables for this dataset are obtained from the WEO (IMF, 2009a). Variables on demographics, aid and remittances are obtained from the World Bank's World Development Indicators database. Effective exchange rate and trade weight data are from the IMF Information Notice System; and net foreign asset data are from the IMF Balance of Payments database. Last, data on armed conflict are taken from the Uppsala Conflict Data Program (2009).

The dataset was adjusted in a number of ways. The following are treated as data errors and excluded from the estimation sample: negative values for nominal GDP, GDP at constant prices, government consumption, exports, imports, population, employment, exchange rate, and terms of trade; and absolute values greater than 100 percent for dependency ratio, population growth, fiscal balance, government spending, current account balance, trade balance, and oil trade balance as a percent of GDP. Trade weight data are replaced by the data reported by country authorities whenever there is a large discrepancy. 
Table 1 summarizes data statistics for the three economic groups of interest: African, LMIC, and advanced economies. Comparing these groups yields three important observations:

1. The macroeconomic balances - in terms of fiscal, government debt, external current account and net foreign asset (NFA) holdings — of the African countries are in general worse than those of LMIC; and these balances for the first two economic groups are worse than those of the advanced economies.

2. African economies are poorer than the LMIC and rely more on foreign aid. Advanced economies, not surprisingly, are significantly richer than the first two economic groups. The mean for real GDP per capita in both the African and LMIC groups in the 2000s are lower than the mean income of advanced economies in the 1970s-80s.

3. Variation across time and country for the advanced economies is much smaller than for the other two economic groups.

Panel unit root test statistics for the variables of interest are provided in the Appendix. Based on these statistics, none of the variables have a unit root that cannot be rejected by a majority of the test results. 
Table 1. Summary Statistics Across Geographic and Economic Regions, 1973-2008

\begin{tabular}{|c|c|c|c|c|c|c|c|c|c|c|c|c|}
\hline & \multicolumn{4}{|c|}{1970 s and $80 \mathrm{~s}$} & \multicolumn{4}{|c|}{$1990 \mathrm{~s}$} & \multicolumn{4}{|c|}{$2000 \mathrm{~s}$} \\
\hline & mean & $\min$ & $\max$ & std dev & mean & $\min$ & $\max$ & std dev & mean & $\min$ & $\max$ & std dev \\
\hline & & & & & & AFRI & & & & & & \\
\hline Gov Cons-to-GDP & 17.82 & 2.01 & 90.76 & 11.36 & 16.36 & 1.48 & 59.73 & 8.99 & 16.08 & 2.29 & 54.80 & 8.11 \\
\hline Fis cal Balance-to-GDP & -6.01 & -34.19 & 19.42 & 6.96 & -4.66 & -48.87 & 15.18 & 6.33 & -1.30 & -39.57 & 40.35 & 8.79 \\
\hline Net Gov Dést Position-to-GDP & 296.50 & 0.00 & 2143.11 & 615.40 & 78.25 & 0.00 & 1010.24 & 137.66 & 48.60 & -79.69 & 259.13 & 59.21 \\
\hline CAB-to-GDP & -6.01 & -98.92 & 54.79 & 14.01 & -6.61 & -90.83 & 22.30 & 11.35 & -4.43 & -94.67 & 44.58 & 12.03 \\
\hline Oil Trade Balance-to-GDP & 0.94 & -79.01 & 63.53 & 12.87 & 3.06 & -9.50 & 85.53 & 14.64 & 4.42 & -21.40 & 94.77 & 22.50 \\
\hline $\mathrm{NFA} / \mathrm{GDP}$ & -24.28 & -46.56 & 71.74 & 29.75 & -43.05 & -205.82 & 91.16 & 63.55 & -56.21 & -497.50 & 109.27 & 91.15 \\
\hline Aid--to-GDP & 10.33 & 0.00 & 70.90 & 10.51 & 13.38 & 0.01 & 80.55 & 12.65 & 11.18 & -0.28 & 95.02 & 12.65 \\
\hline Remmittance-to-GDP & 2.39 & 0.00 & 28.16 & 3.99 & 2.11 & 0.00 & 21.34 & 3.68 & 2.16 & 0.00 & 17.36 & 3.27 \\
\hline \multirow[t]{2}{*}{ Income (PPPpc) } & 1,355 & 30 & 13,280 & 2,055 & 2,125 & 75 & 16,024 & 2,861 & 3,060 & 8 & 20,820 & 3,087 \\
\hline & \multicolumn{12}{|c|}{ LOW A ND MIDDLE INCOME } \\
\hline Gov Cons-to-GDP & 17.83 & 1.16 & 98.31 & 12.98 & 16.41 & 1.48 & 96.52 & 8.74 & 15.76 & 2.29 & 54.80 & 7.04 \\
\hline Fiscal Balance-to-GDP & -4.42 & -69.47 & 74.14 & 10.77 & -4.43 & -56.80 & 22.37 & 6.59 & -1.31 & -39.57 & 42.86 & 7.42 \\
\hline Net Gov Dest Position-to-GDP & 201.48 & 0.00 & 2143.11 & 494.19 & 53.07 & -248.45 & 1010.24 & 94.44 & 41.75 & -185.08 & 259.13 & 54.93 \\
\hline CAB-to-GDP & -3.29 & -98.92 & 97.45 & 15.66 & -5.08 & -90.83 & 71.90 & 11.03 & -3.36 & -94.67 & 78.37 & 12.77 \\
\hline Oil Trade Balance-to-GDP & 1.14 & -79.01 & 87.53 & 13.97 & 2.10 & -43.78 & 85.53 & 13.25 & 2.98 & -35.24 & 94.77 & 18.54 \\
\hline $\mathrm{NFA} / \mathrm{GDP}$ & -23.92 & -200.84 & 102.36 & 34.61 & -32.66 & -205.82 & 91.16 & 48.36 & -45.11 & -497.50 & 109.27 & 64.22 \\
\hline Aid--to-GDP & 8.37 & -0.13 & 460.20 & 15.61 & 8.24 & -0.55 & 82.46 & 10.06 & 6.89 & -2.72 & 00.34 & 11.10 \\
\hline Remmittance-to-GDP & 3.07 & 0.00 & 35.90 & 5.39 & 2.60 & 0.00 & 28.59 & 4.37 & 3.94 & 0.00 & 45.40 & 6.14 \\
\hline \multirow[t]{2}{*}{ Income (PPPp) } & 2,901 & 39 & 47,157 & 4,766 & 4,614 & 75 & 51,132 & 6,044 & 6,857 & 8 & 86,008 & 8,839 \\
\hline & \multicolumn{12}{|c|}{ ADVANCED } \\
\hline Gov Cons-to-GDP & 18.24 & 6.00 & 46.97 & 6.41 & 18.50 & 7.20 & 28.89 & 4.71 & 18.81 & 8.07 & 28.69 & 4.40 \\
\hline Fiscal Balance-to-GDP & -2.45 & -17.63 & 10.03 & 4.45 & -2.44 & -14.51 & 14.28 & 4.12 & -0.17 & -9.85 & 18.77 & 4.22 \\
\hline Net Gov De bt Position-to-GDP & 28.70 & -52.03 & 156.77 & 37.64 & 40.98 & -52.39 & 124.49 & 35.93 & 33.53 & -121.37 & 107.32 & 41.22 \\
\hline CAB-to-GDP & -1.08 & -21.00 & 21.21 & 5.06 & 0.65 & -11.48 & 22.21 & 4.62 & 0.98 & -40.61 & 25.42 & 7.87 \\
\hline Oil Trade Ralance-to-(T)P & -352 & -6951 & 966 & 572 & -104 & -1376 & 1301 & 2.67 & -190 & -953 & 1735 & 361 \\
\hline $\mathrm{NFA} / \mathrm{GDP}$ & -6.56 & -60.22 & 92.41 & 31.74 & -17.50 & -174.89 & 126.55 & 44.32 & 2.16 & -318.32 & 286.27 & 68.69 \\
\hline Aid--to-GDP & 1.68 & -0.24 & 8.44 & 2.21 & 0.47 & -0.04 & 2.99 & 0.71 & 0.17 & -0.07 & 0.67 & 0.20 \\
\hline Remmittance-to-GDP & 0.81 & 0.00 & 10.02 & 1.80 & 0.41 & 0.00 & 5.61 & 0.96 & 0.17 & 0.00 & 2.88 & 0.42 \\
\hline Income (PPPp) & 9,612 & 1,064 & 29,245 & 4,703 & 20,547 & 8,164 & 50,589 & 6,159 & 31.287 & 16,495 & 82,441 & 9,859 \\
\hline
\end{tabular}




\section{Methodology AND Results}

\section{A. Macroeconomic Balance Approach}

\section{Methodology}

The macroeconomic balance approach calculates exchange rate under- or overvaluation by measuring the adjustment needed for the real exchange rate to close the gap between the projected medium-term current account balance at the prevailing real effective exchange rate (REER) and the current account norm that is consistent with the sustainable medium-term macroeconomic fundamentals of a country.

The current account norm is calculated by estimating equation (1) below, for an unbalanced panel of countries, for 1973-2008.

$$
C A B_{i, t}=\alpha_{i}+\beta X_{i, t}+\delta Z_{i, t}+\varepsilon_{i, t}
$$

where $C A B_{i, t}$ is the current account balance as a share of nominal GDP of country $i$ at time $t$. The first term on the right hand-side of the equation is the constant. $X_{i, t}$ is a $T$-by-K matrix composed of $K$ macroeconomic fundamentals that determine the equilibrium value of the current account balance over $T$ periods. The $K$ macroeconomic fundamentals are considered to be the following variables: relative old age dependency, ${ }^{3}$ relative population growth, relative income, relative income growth, relative fiscal balance, oil trade balance, initial NFA, and aid inflows and remittances, as suggested by the CGER ${ }^{4}$ and Vitek (2009). $Z_{i, t}$ is a matrix for the control variables, armed conflict and change in oil production. Finally, $\varepsilon_{i, t}$, is the error term.

Macroeconomic variables in $X_{i, t}$ are expected to affect the current account balance mainly through the savings-investment balance (see Lee et al., 2008; and Isard and Faruqee, 1998).

- Demographics as captured by relative old age dependency and relative population growth $^{5}$ are used to capture the share of nonworking dependent population in a country relative to its trade partners. A larger dependent population is expected to decrease national savings and hence the current account balance.

- The level of economic development is used to establish the capital inflow need of a country. Relative income and relative income growth are used as proxies for stage of economic development. Hence a country which has a low income per capita or is

\footnotetext{
${ }^{3}$ Old age dependency is the old age population as a share of working-age population.

${ }^{4}$ Lee et al. (2008).

${ }^{5}$ Population growth is used as a proxy for young and dependent population.
} 
growing faster than its trading partners would need more investment and have a lower current account balance.

- The fiscal balance is expected to affect national savings as long as the private sector does not fully offset changes in public saving. In this regard, economic theory would expect a positive relationship between the fiscal and current account balances.

- Oil trade balance is a proxy for the impact of oil price and volume changes. For instance, when oil prices increase, the share of oil balance for an oil-exporting country would be higher and so would the current account balance; and the share would be lower-more negative-for an oil-importing country.

- The NFA position is expected to affect the current account balance positively because countries with more NFAs can attract more income flows. However, this variable would have an inverse effect if countries with a low NFA position cannot obtain sufficient financing, and need to adjust their external balance accordingly.

- The direction of the impact of aid on the current account balance depends on its composition (i.e., concessional loans versus official transfers) and its effects on productivity of tradable and nontradable sectors.

- Remittances are expected to positively affect the current account balance with the size of the impact depending on the share of remittances financing imports.

- Two control variables capture the impact of armed conflict and exceptional oil production increases on the current account balance. The former is a dummy variable equal to one whenever the Uppsala database records an armed conflict for country $i$ at time $t$. This variable should control for the changes in the savings-investment decision of a country during times of violent political unrest. The latter control variable is the logarithmic change in a country's oil production for a given period. This variable is used to extract the impact of years, when extraordinary oil production was recorded, from the current account.

Relative variables for old age dependency, population growth, income, income growth, and fiscal balance are calculated to measure how a country performs with respect to its trading partners; these variables are created as given in equation (2).

$$
d x_{i, t}=x_{i, t}-\sum_{j=1}^{N_{i}}\left(w_{i, j} x_{j, t}\right)
$$


where $x_{i, t}$ is the variable of interest for country $i$ at time $t$; and $d x_{i, t}$ is the relative difference of this variable from the weighted average of its $N_{i}$ trading partners. The trade weights, $w_{i, j}$, are obtained from the IMF Information Notice System database. ${ }^{6}$

\section{Estimation results}

Equation (2) is estimated by the panel generalized method of moments methodology by controlling for White standard errors and covariance matrix for four samples: the whole sample, LMIC, sub-Saharan African economies, and sub-Saharan African economies excluding oil exporters. ${ }^{7}$ Equation (2) is estimated for each sample as is under the unrestricted model column of Table 2; and then the most efficient model for each sample is obtained by using the general-to-specific estimation method and these results are reported under the restricted model column. Estimation results are reported in Table 2 together with the CGER coefficients (Lee et al., 2008).

Coefficient estimates for the whole sample and the LMIC sample are quite similar to those of the CGER estimates in both sign and magnitude except for population growth and income growth (see Table 2). The former variable is insignificant in both the whole sample and LMIC sample. On the other hand, relative income growth is significant in the whole sample and in the LMIC sample, and the coefficient estimates from these two samples are much larger than in the CGER estimates, reflecting the impact of the developing economies, which constitutes a smaller share of the CGER sample.

The sub-Saharan economies sample shows considerable differences in econometric estimates from the other samples. First, demographics do not have explanatory power for this sample, but relative stage of development, as measured by relative income, is more important. A 1 percent increase in relative income in the sub-Saharan Africa sample tends to improve the current account balance by 0.07 percent, whereas this effect is less than or equal to 0.02 percent in other economies.

Second, the fiscal balance has a major impact on the investment-saving equilibrium of subSaharan Africa, where a 1 percent fiscal-gap strengthening improves the current account balance by 1 percent. This relationship is much weaker in other samples: 0.3 percent or less.

Third, foreign income inflows through aid and remittances improve the current account balance in sub-Saharan Africa but are statistically insignificant in other economies.

\footnotetext{
${ }^{6}$ This database reports trade weights for three periods: 1973-1989, 1990-1995, and 1996-2008. The trade weight matrix is spliced from these three periods.

${ }^{7}$ For the LMIC and the sub-Saharan Africa sample, the estimation sample starts from 1990, as many of the countries in these groups gained their independence around this period.
} 
Table 2. Macroeconomic Balance Estimation Results (Dependent Variable: CAB/GDP)

\begin{tabular}{|c|c|c|c|c|c|c|c|c|c|c|c|}
\hline & \multicolumn{3}{|c|}{ CGER $^{1}$} & \multicolumn{2}{|c|}{ Whole Sample } & \multicolumn{2}{|c|}{ LMIC $^{2}$} & \multicolumn{2}{|c|}{ Afric $^{2}$} & \multicolumn{2}{|c|}{ Afric a (Non-Oil Exporting) $)^{2}$} \\
\hline & Pooled & Hybred Pooled & Fixed Effecte & Unrestricted & Restricted & Unrestricted & Restricted & Unrestricted $\mathrm{F}$ & Restricted & Unrestricted & Restricted \\
\hline Relative old-age dependency & $-0.14 * * *$ & $-0.12 * * *$ & $-0.23 * * *$ & $\begin{array}{l}-0.11 \\
-0.91\end{array}$ & $\begin{array}{l}-0.16^{*} \\
-1.42\end{array}$ & $\begin{array}{l}-0.18 \\
-1.10\end{array}$ & $\begin{array}{l}-0.27 * * \\
-2.02\end{array}$ & $\begin{array}{l}-0.09 \\
-0.33\end{array}$ & & $\begin{array}{l}-0.15 \\
-0.43\end{array}$ & \\
\hline Relative population growth & $-1.21 * * * *$ & $-1.03 * * *$ & -0.47 & $\begin{array}{l}0.31 \\
0.90\end{array}$ & & $\begin{array}{l}0.58 \text { * } \\
1.75\end{array}$ & & $\begin{array}{l}0.96 \\
1.08\end{array}$ & & $\begin{array}{l}-0.59 \\
-0.69\end{array}$ & \\
\hline Relative income (PPP.c.) & $0.02 * *$ & $0.02 * *$ & & $\begin{array}{l}0.01 \\
1.25\end{array}$ & $\begin{array}{l}0.01 \\
1.09\end{array}$ & $\begin{array}{l}0.01 \\
0.84\end{array}$ & $\begin{array}{l}0.01 * * \\
1.65\end{array}$ & $\begin{array}{l}0.08 * * * * \\
3.46\end{array}$ & $\begin{array}{l}0.07 * * * * \\
4.16\end{array}$ & $\begin{array}{l}0.12 * * \\
1.90\end{array}$ & $\begin{array}{l}0.08 * * * \\
3.45\end{array}$ \\
\hline Relative income growth & $-0.21 * * *$ & $-0.16 * *$ & -0.27 & $\begin{array}{l}-0.47 * * \\
-1.80\end{array}$ & $\begin{array}{l}-0.46 * * * \\
-2.36\end{array}$ & $\begin{array}{l}-0.41 \\
-1.18\end{array}$ & $\begin{array}{l}-0.37 * * \\
-1.73\end{array}$ & $\begin{array}{l}0.12 \\
0.12\end{array}$ & & $\begin{array}{l}-0.02 \\
-0.02\end{array}$ & \\
\hline Oil Trade Balance-to-GDP & $0.23 * * * *$ & $0.17^{* * * *}$ & $0.31 * * * *$ & $\begin{array}{l}0.39 * * * * \\
5.04\end{array}$ & $\begin{array}{l}0.36 * * * * \\
5.90\end{array}$ & $\begin{array}{l}0.38 * * * * \\
3.60\end{array}$ & $\begin{array}{l}0.34 * * * * \\
5.07\end{array}$ & $\begin{array}{l}0.13 \\
0.74\end{array}$ & $\begin{array}{l}0.18^{* * *} \\
1.99\end{array}$ & $\begin{array}{l}1.87^{* *} \\
1.83\end{array}$ & $\begin{array}{l}1.10 * * * \\
2.56\end{array}$ \\
\hline Relative Fiscal Balance-to-GDP & $0.20 * * * *$ & $0.19 * * * *$ & $0.32 * * * *$ & $\begin{array}{l}0.13 \\
1.03\end{array}$ & $\begin{array}{l}0.18 * \\
1.4 !\end{array}$ & $\begin{array}{l}0.06 \\
0.33\end{array}$ & $\begin{array}{l}0.15 \\
0.85\end{array}$ & $\begin{array}{l}1.26 * * \\
1.74\end{array}$ & $\begin{array}{l}1.04 * 8 \\
1.96\end{array}$ & $\begin{array}{l}2.30 * \\
1.31\end{array}$ & $\begin{array}{l}1.23 * \\
1.52\end{array}$ \\
\hline NFA-to-GPP(-1) & $0.02 * * * *$ & & & $\begin{array}{l}0.04^{* * * 8} \\
4.16\end{array}$ & $\begin{array}{l}0.04^{* * * *} \\
3.9 \text { ! }\end{array}$ & $\begin{array}{l}0.03 * * * \\
2.11\end{array}$ & $\begin{array}{l}0.02 * * * \\
1.86\end{array}$ & $\begin{array}{l}-0.02 \\
-0.79\end{array}$ & $\begin{array}{l}-0.02 \\
-1.23\end{array}$ & $\begin{array}{l}-0.04 \\
-0.95\end{array}$ & $\begin{array}{l}-0.03 * \\
-1.48\end{array}$ \\
\hline Aid-to-GDP & & & & $\begin{array}{l}0.13 \\
0.92\end{array}$ & $\begin{array}{l}0.10 \\
0.77\end{array}$ & $\begin{array}{l}-0.01 \\
-0.04\end{array}$ & & $\begin{array}{l}0.31 * \\
1.67\end{array}$ & $\begin{array}{l}0.26 * \\
1.59\end{array}$ & $\begin{array}{l}0.70 \text { * } \\
1.66\end{array}$ & $\begin{array}{l}0.34 * \\
1.63\end{array}$ \\
\hline Remittances-to-GDP & & & & $\begin{array}{l}0.14 \\
1.04\end{array}$ & & $\begin{array}{l}0.07 \\
0.56\end{array}$ & & $\begin{array}{l}0.48 \\
1.21\end{array}$ & $\begin{array}{l}0.45 * \\
1.40\end{array}$ & $\begin{array}{l}0.57 \\
1.27\end{array}$ & \\
\hline Conflict & & & & $\begin{array}{r}0.00 \\
-0.02\end{array}$ & & $\begin{array}{l}0.00 \\
0.28\end{array}$ & $\begin{array}{l}0.01 \\
0.87\end{array}$ & $\begin{array}{l}-0.02 \\
-0.99\end{array}$ & & $\begin{array}{l}-0.01 \\
-0.28\end{array}$ & \\
\hline Change in Oil Production & & & & $\begin{array}{l}-0.10 \\
-0.63\end{array}$ & & $\begin{array}{l}-0.05 \\
-0.16\end{array}$ & & $\begin{array}{l}9.34 \\
0.48\end{array}$ & $\begin{array}{l}12.79 * * \\
1.96\end{array}$ & & \\
\hline $\begin{array}{l}\text { Number of Observations } \\
\text { Std Error of Regression } \\
\text { Sum of Squared Residuals }\end{array}$ & & & & $\begin{array}{r}1021 \\
0.07 \\
4.36\end{array}$ & $\begin{array}{l}1124 \\
0.07 \\
4.74\end{array}$ & $\begin{array}{l}600 \\
0.07 \\
3.09\end{array}$ & $\begin{array}{r}703 \\
0.07 \\
3.45\end{array}$ & $\begin{array}{l}161 \\
0.09 \\
1.20\end{array}$ & $\begin{array}{l}199 \\
0.08 \\
0.99\end{array}$ & $\begin{array}{l}154 \\
0.14 \\
2.61\end{array}$ & $\begin{array}{l}190 \\
0.08 \\
1.07\end{array}$ \\
\hline $\begin{array}{l}\text { Notes: } \\
{ }^{1} \text { : Lee et al. (2008), pag e } 5 \text {. } \\
2 \text {. Sample period from } 1990 \text { to } 20 \\
\text { t-statistics are provided beneath } \\
\text { One-sided statistical signifincan }\end{array}$ & $\begin{array}{l}\text { os. } \\
\text { h the coefficient } \\
\text { ace at } 1,5,10 \text { an }\end{array}$ & $\begin{array}{l}\text { estimates in } \mathrm{sm} \\
\mathrm{d} 20 \text { percent lev }\end{array}$ & $\begin{array}{l}\text { nalleritalic font. } \\
\text { vel are indicated }\end{array}$ & $* * *, * * *, * *$ & ${ }^{*}$ and ${ }^{*}$, respe & & & & & & \\
\hline
\end{tabular}


Finally, the control dummy for percentage change in oil production is significant and large in magnitude in the African sample, but it is statistically insignificant in other samples. That is why in the last estimation sample, we exclude oil exporters from the sub-Saharan Africa sample. Their exclusion tends to increase the impact of oil trade balance on the current account even further, so that a 1 percent decline in the oil trade balance reduces the current account balance by 1.1 percent.

Last, the impact of fiscal dominance gets larger in oil-importing African countries. A 1 percent decline in fiscal savings reduces external balance by more than 1 percent.

\section{Exchange rate assessment}

The current account norms are calculated using the estimated coefficients of the restricted model (see Table 2). The norms show the equilibrium level of the current account balance based on the assumption that over the medium term macroeconomic fundamentals reach their equilibrium values. The medium-term figures are taken from the October 2009 WEO database. $^{8}$

The current account gap is estimated by taking the difference between the estimated current account norm and the underlying current account balance. The underlying balance is the 2014 current account projection, reported in the October 2009 WEO database, which is based on a constant real exchange rate path where an economy reaches internal equilibrium-zero output gap. The focus is on 2014, when the external balance should be in equilibrium because the years leading up to it are considered to be a transitionary period. Table 3 reports the current account norm, underlying current account balance and the current account gap for all sub-Saharan African countries with sufficient data available to solve for the restricted model (Table 2, column 9).

The degree of under- or overvaluation is determined based on the size of the gap between the underlying and the current account norm and the elasticity of the current account balance with respect to the real exchange rate. A country where the elasticity is higher needs a smaller real exchange rate adjustment to close the gap between the norm and the underlying balance.

To calculate the elasticity of the current account balance with respect to the real exchange rate, one can use the assumptions 0.92 for import elasticity, $\varepsilon_{R E R}^{I M}$, and -0.71 for export elasticity, $\varepsilon_{R E R}^{X}$, based on the findings of Isard and Faruqee (1998).

\footnotetext{
${ }^{8}$ Note that the current account norm would not yield a sustainable external balance unless the macroeconomic fundamentals used to derive it are sustained.
} 
Table 3. Macroeconomic Balance Assessment of Sub-Saharan Africa

\begin{tabular}{|c|c|c|c|c|c|c|c|}
\hline & \multicolumn{7}{|c|}{$\mathrm{CAB} / \mathrm{GDP}$} \\
\hline & \multicolumn{3}{|c|}{ NORM } & \multirow[t]{2}{*}{ Underlying } & \multicolumn{3}{|c|}{ GAP } \\
\hline & Lower & Mean & Upper & & Lower & Mean & Upper \\
\hline Angola & 3.6 & 10.7 & 17.8 & 4.1 & -13.8 & -6.7 & 0.4 \\
\hline Botswana & -3.6 & 9.0 & 21.7 & 3.3 & -18.4 & -5.7 & 6.9 \\
\hline Burundi & -41.2 & -6.3 & 28.6 & -9.7 & -38.2 & -3.3 & 31.6 \\
\hline Côte d'Ivoire & -21.7 & -12.1 & -2.4 & -4.0 & -1.6 & 8.0 & 17.7 \\
\hline Djibouti & -15.3 & 1.9 & 19.0 & -19.9 & -39.0 & -21.8 & -4.7 \\
\hline Guinea & -42.4 & -12.5 & 17.4 & -3.8 & -21.2 & 8.7 & 38.5 \\
\hline Guinea-Bissau & -12.8 & 2.3 & 17.5 & -6.4 & -23.9 & -8.8 & 6.4 \\
\hline Lesotho & -17.7 & -6.9 & 3.9 & -20.5 & -24.4 & -13.6 & -2.8 \\
\hline Mali & -15.6 & -3.1 & 9.5 & -7.9 & -17.4 & -4.8 & 7.8 \\
\hline Mauritius & -9.8 & 3.7 & 17.2 & -7.0 & -24.2 & -10.7 & 2.8 \\
\hline Mozambique & -10.1 & -5.9 & -1.8 & -11.2 & -9.4 & -5.3 & -1.1 \\
\hline Namibia & -7.4 & 0.0 & 7.3 & -0.8 & -8.1 & -0.8 & 6.6 \\
\hline Niger & -27.4 & -6.9 & 13.6 & -6.6 & -20.2 & 0.3 & 20.7 \\
\hline Nigeria & -21.7 & 5.3 & 32.3 & 14.5 & -17.8 & 9.2 & 36.1 \\
\hline Rwanda & -13.8 & -6.4 & 1.0 & -7.0 & -8.0 & -0.6 & 6.7 \\
\hline Senegal & -9.2 & -3.6 & 2.1 & -10.4 & -12.4 & -6.8 & -1.2 \\
\hline Sierra Leone & -19.6 & -5.0 & 9.5 & -5.5 & -15.1 & -0.5 & 14.1 \\
\hline South Africa & -6.6 & 1.5 & 9.6 & -7.5 & -17.1 & -9.0 & -0.9 \\
\hline Swaziland & -7.7 & 0.7 & 9.2 & -3.6 & -12.8 & -4.3 & 4.1 \\
\hline Tanzania & -12.7 & -6.4 & 0.0 & -9.1 & -9.1 & -2.8 & 3.5 \\
\hline Uganda & -7.0 & -0.5 & 6.0 & -4.5 & -10.4 & -3.9 & 2.6 \\
\hline
\end{tabular}

Note: Lower and upper bands are based on 90-percent confidence interval of the in-sample model fit. 
For illustrative purposes, the elasticity of the current account balance with respect to the real exchange rate, $\varepsilon_{R E R}^{C A B}$, is calculated as follows:

$$
\varepsilon_{R E R}^{C A B}=\frac{X}{G D P} \varepsilon_{R E R}^{X}-\frac{I M}{G D P}\left(\varepsilon_{R E R}^{I M}-1\right)
$$

The degree of under- or overvaluation is calculated as follows:

$$
\triangle R E R=\frac{\left(C A B^{U}-C A B^{N}\right)}{\varepsilon_{R E R}^{C A B}}
$$

where $\triangle R E R$ shows the percentage change in the REER: a positive value indicates overvaluation, a negative shows undervaluation. $C A B^{U}$ is the underlying current account balance, and $C A B^{N}$ is the current account norm.

\section{Robustness}

Previous analyses of the equilibrium exchange rate used nonoverlapping four-year averages to exclude business cycle fluctuations in the data. Here we mainly use annual data rather than four-year averages for two reasons: (1) The start date and duration of business cycles across countries may not overlap with the start dates of the four-year averages. (2) Four-year averaging excludes many countries that have few time series data and eliminates variations in the dataset which would decrease the efficiency of the econometric estimates.

Nevertheless, in this section we apply the panel GMM estimation to a nonoverlapping sample of four-year averaged data ${ }^{9}$ (see Table 4). The sign, magnitude, and t-statistics of the estimated coefficients are quite similar for both the four-year averaged and annual data estimation results for both the whole and the LMIC samples. However, data limitations prevent estimation of panel GMM coefficients for the sub-Saharan Africa sample.

Then the panel GMM model is estimated for each sample, excluding data that are six standard deviations away from the mean in order to observe whether any of the coefficient estimates are driven by extraordinary country-time observations. In fact, the coefficient estimates and the significance levels are not driven by the outliers. ${ }^{10}$

\footnotetext{
${ }^{9}$ Similarly, Chinn and Prasad (2003), estimating the macroeconomic balance approach by using panel ordinary least squares methodology, show that results do not vary by data frequency, i.e., four-year averages versus annual data.

${ }^{10}$ Due to space limitations, results of this analysis are not reported in this paper.
} 


\section{Table 4. Macroeconomic Balance Estimation Results with Nonoverlapping Four-year-Averages}

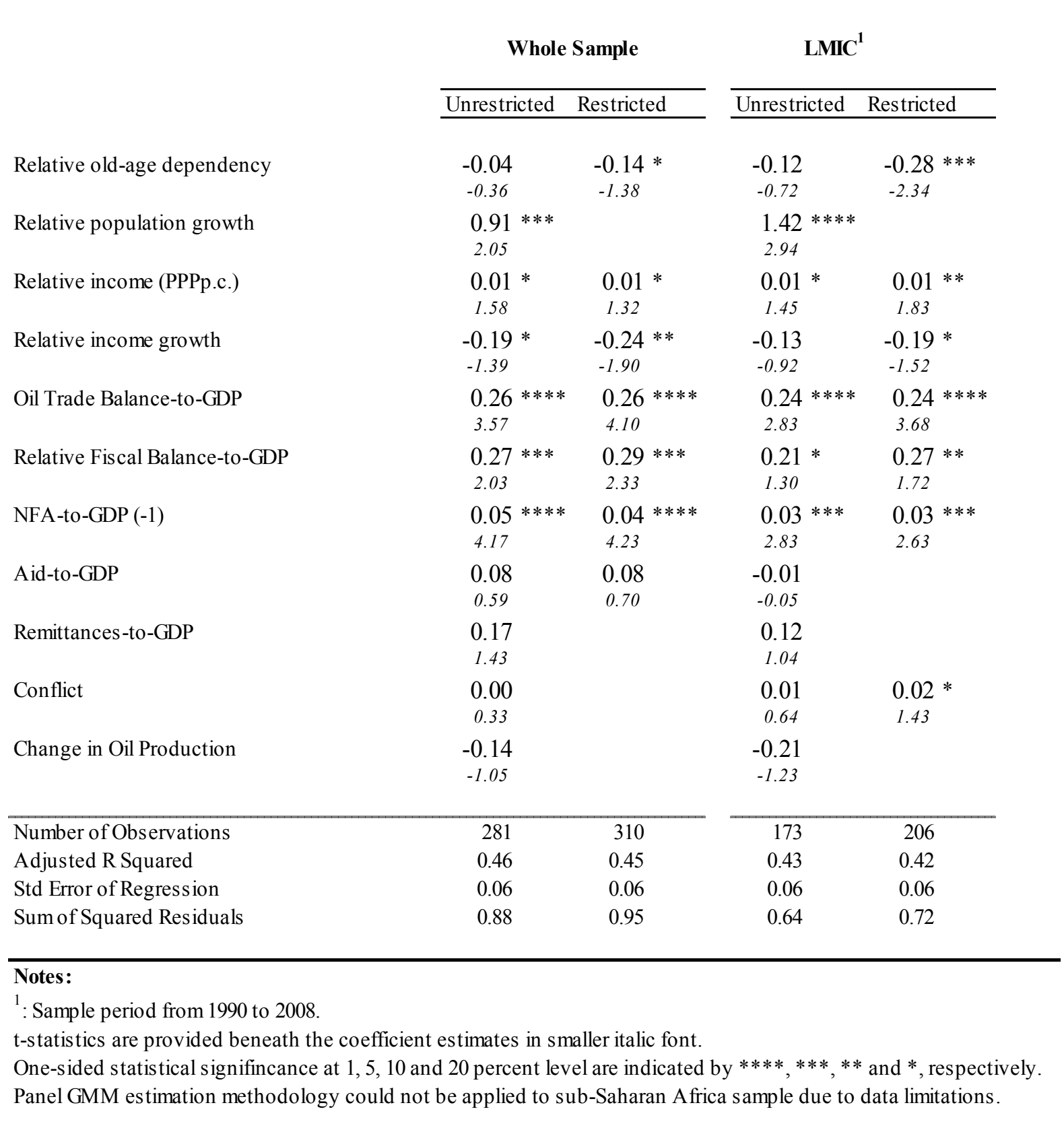

Last, we control for excessive real GDP growth periods to see whether they have significant effects on an economy's savings-investment balances. We include a 0-1 dummy variable for two or more consecutive periods of real GDP growth higher than 10 and 15 percent. These dummies are not to have explanatory power. ${ }^{11}$

${ }^{11}$ Due to space limitations, results of this analysis are not reported in this paper. 


\section{B. Equilibrium Real Exchange Rate Approach}

\section{Methodology}

In the equilibrium real exchange rate approach, the degree of under- or overvaluation is measured by the percentage deviation of the exchange rate from its equilibrium value. The medium-term equilibrium value of the REER is estimated in the following panel regression:

$$
\ln R E R_{i, t}=\alpha_{i}+\beta X_{i, t}+\varepsilon_{i, t}
$$

where $R E R_{i, t}$ is the REER of country $i$ at time $t$. The first term on the right hand-side of the equation is the constant. $X_{i, t}$ is a $T$ - $b y-K$ matrix composed of $K$ macroeconomic fundamentals that determine the equilibrium value of the real exchange rate. The $K$ fundamentals as suggested by the CGER ${ }^{12}$ and Vitek (2009) are terms of trade, relative productivity measured by GDP at a purchasing power parity exchange rate per unit of labor, the government consumption to GDP ratio relative to trading partners, NFA, aid inflows, and remittance inflows. Finally, $\varepsilon_{i, t}$ is the error term.

- An increase in terms of trade would be expected to cause the real exchange rate to appreciate through a pass-through in higher income or wealth effect and its impact through the change in relative prices.

- Relative productivity is measured as the difference between a country's real output per unit of labor and real labor productivity in its trading partners. Assuming that labor is mobile across sectors, higher productivity would put pressure on wages in both tradable and nontradable sectors and hence on prices and would cause the real exchange rate in the tradable sector to appreciate.

- Relative government consumption as a share of GDP should also have a positive impact on the real exchange rate, assuming that most government consumption is in the nontradable sector.

- The ratio of the NFA to GDP is expected to have a positive impact on the real exchange rate because a debtor country would need a depreciated real exchange rate to boost its export income so as to service its external liabilities, and vice versa for the creditor countries.

- The impact of aid and remittances on the real exchange rate depends on whether these flows help to improve on a country's productivity. Mongardini and Rayner (2006) argue that if grants and remittances are spent to ease supply constraints or increase

\footnotetext{
${ }^{12}$ Lee et al. (2008).
} 
productivity in the nontradable sector, then that would lead to exchange rate depreciation in the medium term.

Finally, variables, relative to those of a country's trading partners, for terms of trade and government consumption are calculated as given in equation (2) in the macroeconomic balance approach section.

\section{Estimation results and exchange rate assessment}

Estimation results of equation (5) are reported in Table 5 together with the CGER estimates (Lee et al., 2008). Equation (5) is reported in the unrestricted estimation column, and the most efficient model, through the general to specific estimation, is reported in the restricted column. Compared to the CGER estimates, with panel GMM regression only terms of trade and relative productivity determine the equilibrium real exchange rate, and the coefficient estimates of these variables are similar in magnitude to those of the CGER.

In addition to the CGER variables, aid inflows have explanatory power in the GMM estimates. A 1 percent increase in aid inflows tends to depreciate a country's exchange rate by 0.9 percent for the whole sample. This finding may have reflected the productivityenhancing effects of aid on the nontradable sector (e.g., infrastructure) whose relative prices may have declined vis-a-vis the tradable sector that experienced slower productivity growth.

Coefficient estimates for African countries are similar in magnitude to those of the whole and the LMIC samples; however, for non-oil-exporting African countries, terms of trade has a smaller impact and relative productivity and aid inflows have much larger effects on the equilibrium real exchange rate.

Based on these estimation results, equilibrium real exchange rates can be calculated from the medium-term macroeconomic fundamentals. Then the exchange rate under- or overvaluation can be measured by the percent deviation of the observed exchange rate from its equilibrium value. 
Table 5. Equilibrium Real Exchange Rate Estimation Results

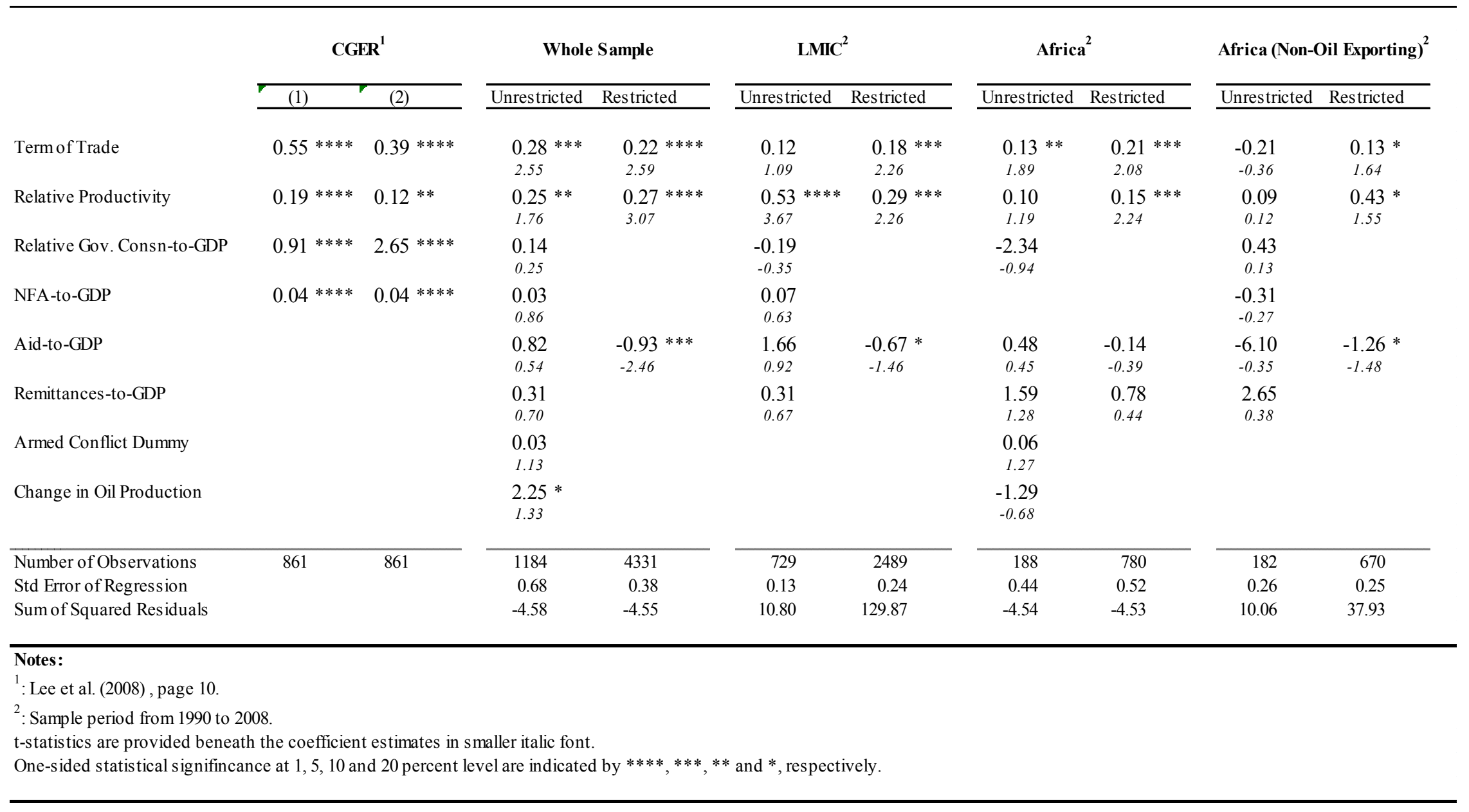




\section{Robustness}

As we did with the macroeconomic balance approach, we apply the panel GMM estimation to a nonoverlapping sample of four-year averaged data, finding that the sign, magnitude, and t-statistics of the estimated coefficients are quite similar to the annual data estimation results for both the whole and the LMIC samples. ${ }^{13}$

We then control for armed conflict and oil production in equation (5). Unlike our finding for the previous approach, these two control variables do not have explanatory power in determining the exchange rate (see Table 6).

Then a panel GMM model is estimated for each sample excluding data that are six standard deviations away from the mean so as to observe whether any of the coefficient estimates are driven by extraordinary observations. We find that coefficient estimates and significance levels are not driven by outliers. ${ }^{14}$

Last, we control for exceptionally high real GDP growth periods to see whether such periods influence the savings-investment behavior of an economy. We include a $0-1$ dummy variable for two or more consecutive periods of real GDP growth higher than 10 and 15 percent, and find that these dummies do not have explanatory power. ${ }^{15}$

\footnotetext{
${ }^{13}$ Due to space limitations, results of this analysis are not reported in this paper.

${ }^{14}$ Due to space limitations, results of this analysis are not reported here.

${ }^{15}$ Due to space limitations, results of this analysis are not reported in this paper.
} 


\section{Table 6. Equilibrium Real Exchange Rate Estimation Results Controlling for Armed Conflict and Oil Production}

\begin{tabular}{|c|c|c|c|c|c|c|c|c|}
\hline & \multicolumn{2}{|c|}{ Whole Sample } & \multicolumn{2}{|c|}{ Non-Advanced $^{1}$} & \multicolumn{2}{|c|}{ Africa ${ }^{1}$} & \multicolumn{2}{|c|}{ Africa (Non-Oil Exporting) } \\
\hline & Unrestricted & Restricted & Unrestricted & Restricted & Unrestricted & Restricted & Unrestricted & Restricted \\
\hline Term of Trade & $\begin{array}{l}0.28 * * * \\
2.55\end{array}$ & $\begin{array}{l}0.33 * * * * \\
3.92\end{array}$ & $\begin{array}{l}0.12 \\
1.09\end{array}$ & $\begin{array}{l}0.18 * * * \\
2.26\end{array}$ & $\begin{array}{l}0.13 * * \\
1.89\end{array}$ & $\begin{array}{l}0.21 * * * \\
2.08\end{array}$ & $\begin{array}{l}-0.21 \\
-0.36\end{array}$ & $\begin{array}{l}0.13 * \\
1.64\end{array}$ \\
\hline Relative Productivity & $\begin{array}{l}0.25 * * \\
1.76\end{array}$ & $\begin{array}{l}0.38 * * * * \\
3.14\end{array}$ & $\begin{array}{l}0.53 * * * * \\
3.67\end{array}$ & $\begin{array}{l}0.29 * * * \\
2.26\end{array}$ & $\begin{array}{l}0.10 \\
1.19\end{array}$ & $\begin{array}{l}0.15 * * * \\
2.24\end{array}$ & $\begin{array}{l}0.09 \\
0.12\end{array}$ & $\begin{array}{l}0.43 * \\
1.55\end{array}$ \\
\hline Relative Gov. Consn-to-GDP & $\begin{array}{c}0.14 \\
0.25\end{array}$ & & $\begin{array}{l}-0.19 \\
-0.35\end{array}$ & & $\begin{array}{l}-2.34 \\
-0.94\end{array}$ & & $\begin{array}{l}0.43 \\
0.13\end{array}$ & \\
\hline NFA-to-GDP & $\begin{array}{l}0.03 \\
0.86\end{array}$ & & $\begin{array}{c}0.07 \\
0.63\end{array}$ & & & & $\begin{array}{l}-0.31 \\
-0.27\end{array}$ & \\
\hline Aid-to-GDP & $\begin{array}{c}0.82 \\
0.54\end{array}$ & $\begin{array}{l}-0.26 \\
-0.60\end{array}$ & $\begin{array}{l}1.66 \\
0.92\end{array}$ & $\begin{array}{l}-0.67 * \\
-1.46\end{array}$ & $\begin{array}{c}0.48 \\
0.45\end{array}$ & $\begin{array}{l}-0.14 \\
-0.39\end{array}$ & $\begin{array}{l}-6.10 \\
-0.35\end{array}$ & $\begin{array}{l}-1.26 * \\
-1.48\end{array}$ \\
\hline Remittances-to-GDP & $\begin{array}{c}0.31 \\
0.70\end{array}$ & $\begin{array}{l}0.87 * \\
1.64\end{array}$ & $\begin{array}{c}0.31 \\
0.67\end{array}$ & & $\begin{array}{l}1.59 \\
1.28\end{array}$ & $\begin{array}{c}0.78 \\
0.44\end{array}$ & $\begin{array}{c}2.65 \\
0.38\end{array}$ & \\
\hline Armed Conflict Dummy & $\begin{array}{l}0.03 \\
1.13\end{array}$ & & & & $\begin{array}{l}0.06 \\
1.27\end{array}$ & & & \\
\hline Change in Oil Production & $\begin{array}{l}2.25 * \\
1.33\end{array}$ & & & & $\begin{array}{l}-1.29 \\
-0.68\end{array}$ & & & \\
\hline Number of Observations & 1184 & 4331 & 729 & 2489 & 188 & 780 & 182 & 670 \\
\hline Adjusted R Squared & 0.00 & 0.00 & 0.69 & 0.28 & 0.00 & 0.00 & -0.38 & 0.22 \\
\hline Std Error of Regression & 0.68 & 0.45 & 0.13 & 0.24 & 0.44 & 0.52 & 0.26 & 0.25 \\
\hline Sum of Squared Residuals & -4.58 & -4.54 & 10.80 & 129.87 & -4.54 & -4.53 & 10.06 & 37.93 \\
\hline \multicolumn{9}{|c|}{$\begin{array}{l}\text { Notes: } \\
{ }^{1}: \text { Sample period from } 1990 \text { to } 2008 \text {. } \\
\text { t-statistics are provided beneath the coefficient estimates in smaller italic font. } \\
\text { One-sided statistical signifincance at } 1,5,10 \text { and } 20 \text { percent level are indicated by } * * * * * * *, * * \text { and }{ }^{*} \text {, respectively. }\end{array}$} \\
\hline
\end{tabular}




\section{External Sustainability Approach}

\section{Methodology}

As in the macroeconomic balance approach, in the external sustainability approach the degree of exchange rate under- and overvaluation is measured by how much the exchange rate needs to adjust to close the gap between the projected current account position-with no change in the exchange rate path - and the current account norm.

In this approach, the norm is calculated as the current account balance stabilizing "normative" NFA position:

$$
C A B_{i}^{n}=\frac{g_{t}}{1+g_{t}} N F A_{i}^{n}
$$

The norm value of a country's NFA position can either be calibrated or estimated.

Following the literature on the external sustainability approach, we calibrate the norm NFA position to the most recent net international investment position observation for a country, which is the 2008 value given in the IMF Balance of Payments database. ${ }^{16}$

\section{Exchange rate assessment}

The current account balance that would stabilize the calibrated NFA position is calculated based on equation (6). Any deviation between the norm and the underlying current account balance is the gap. ${ }^{17}$ See Table 7 for the values of the NFA position of the sub-Saharan African countries and the current account norms and the gaps based on these positions.

The change in the real exchange rate that is required to close the gap between the underlying and the norm current account balances is calculated by using the elasticity of the current account with respect to the real exchange rate. As with the macroeconomic balance approach, import elasticity of 0.92 and export elasticity of -0.71 is assumed. Real exchange rate assessment is the change in the real exchange rate that would close this gap.

\footnotetext{
${ }^{16}$ The NFA position for Botswana - an exporter of an exhaustible resource-is calculated consistent with its medium-term fiscal sustainability as discussed by Deléchat and Gaertner (2008).

${ }^{17}$ As with to the macroeconomic balance approach, the underlying current account balance is the 2014 current account balance projection reported in the October 2009 WEO.
} 
Table 7. External Sustainability Assessment of Sub-Saharan Africa

\begin{tabular}{|c|c|c|c|c|c|}
\hline & \multirow{2}{*}{ NFA/GDP } & \multirow{2}{*}{$\begin{array}{l}\text { Nominal } \\
\text { Growth }\end{array}$} & \multicolumn{3}{|c|}{$\mathrm{CAB} / \mathrm{GDP}$} \\
\hline & & & NORM & Underlying & GAP \\
\hline Angola & 15.2 & 18.0 & 2.3 & 4.1 & 1.8 \\
\hline Benin & -7.3 & 8.5 & -0.6 & -6.6 & -6.1 \\
\hline Botswana & 73.3 & 6.0 & 4.1 & 3.3 & -0.8 \\
\hline Burkina Faso & -64.7 & 7.8 & -4.7 & -9.0 & -4.3 \\
\hline Burundi & -97.8 & 9.9 & -8.8 & -9.7 & -0.9 \\
\hline Côte d'Ivoire & -53.6 & 8.7 & -4.3 & -4.0 & 0.3 \\
\hline Djibouti & 24.4 & 9.9 & 2.2 & -19.9 & -22.1 \\
\hline Guinea & -16.6 & 10.3 & -1.5 & -3.8 & -2.3 \\
\hline Guinea-Bissau & -329.1 & 5.9 & -18.3 & -6.4 & 11.8 \\
\hline Lesotho & 31.3 & 8.6 & 2.5 & -20.5 & -23.0 \\
\hline Mali & -26.6 & 7.8 & -1.9 & -7.9 & -5.9 \\
\hline Mauritius & 9.9 & 8.8 & 0.8 & -7.0 & -7.8 \\
\hline Mozambique & -70.9 & 11.2 & -7.1 & -11.2 & -4.1 \\
\hline Namibia & 44.0 & 7.2 & 3.0 & -0.8 & -3.8 \\
\hline Niger & -23.3 & 7.7 & -1.7 & -6.6 & -5.0 \\
\hline Nigeria & 31.5 & 14.3 & 3.9 & 14.5 & 10.5 \\
\hline Rwanda & -3.1 & 10.9 & -0.3 & -7.0 & -6.7 \\
\hline Senegal & -35.8 & 6.9 & -2.3 & -10.4 & -8.1 \\
\hline Sierra Leone & -34.9 & 9.7 & -3.1 & -5.5 & -2.5 \\
\hline South Africa & -36.2 & 10.0 & -3.3 & -7.5 & -4.2 \\
\hline Swaziland & 51.2 & 7.5 & 3.6 & -3.6 & -7.2 \\
\hline Tanzania & -44.8 & 12.1 & -4.8 & -9.1 & -4.3 \\
\hline Togo & -95.7 & 6.6 & -5.9 & 0.2 & 6.1 \\
\hline Uganda & -29.2 & 11.3 & -3.0 & -4.5 & -1.5 \\
\hline
\end{tabular}




\section{Purchasing Power Parity Approach}

\section{Methodology}

The purchasing power parity (PPP) approach relies on the assumption that nominal exchange rates are related to national price levels, and changes in the former should be in line with changes in relative price levels. Based on this theory, we can express the nominal exchange rate, $E_{i, j}$, between country $i$ and $j$ as the relationship given in equation (7):

$$
E_{i, j}=C \frac{P_{i}}{P_{j}}
$$

where $C$ is a constant equal to 1 based on the absolute PPP hypothesis or a positive number based on the relative PPP hypothesis that is equal to the proportionate relationship between the nominal exchange rate $E_{i, j}$ and the ratio of the national price level $P_{i}$ of country $i$ to the foreign price level $P_{j}$.

By leaving $C$ on the right side of equation (8) and taking the logarithm of both sides, we can express the logarithm of the real exchange rate $\operatorname{rer}_{i, t}$ as: ${ }^{18}$

$$
\operatorname{rer}_{i, t}=c
$$

Based on equation (8), the PPP theory suggests that the equilibrium level of the real exchange rate can be approximated by a constant, and the level of the real exchange rate should converge to this constant in the long run. Comparison of this long run value with the prevailing rate of exchange rate will determine the exchange rate under- or overvaluation.

\section{Estimation results and exchange rate assessment}

Table 8 provides the estimation results of equation (8) based on the pooled GMM methodology with fixed effects. The first column shows results for the whole sample, the second for the LMIC, the third for sub-Saharan African economies, and the last for non-oilexporting sub-Saharan African economies. Based on the fixed effect country coefficients and the constant, $c$, estimated from equation (8), equilibrium real exchange rate of each of the sub-Saharan African country is calculated.

The assessment of the real exchange rate in this methodology will be based on the percentage deviation of the underlying real exchange rate from the equilibrium which is calculated by relying on the coefficients estimated through the PPP approach.

\footnotetext{
${ }^{18}$ Lower case letters in equation (8) indicates logarithms of the variables in equation (7).
} 
Table 8. Purchasing Power Parity Estimation Results

\begin{tabular}{|c|c|c|c|c|}
\hline & Whole Sample & LMIC $^{1}$ & Africa ${ }^{1}$ & Africa (Non-Oil Exporting) ${ }^{1}$ \\
\hline Constant & $\begin{array}{l}0.07 \text { **** } \\
3 . E+16\end{array}$ & $\begin{array}{l}-0.01 * * * * \\
-9 . E+15\end{array}$ & $\begin{array}{l}0.02 \text { **** } \\
5 . E+15\end{array}$ & $\begin{array}{l}0.00 * * * * \\
1 . E+15\end{array}$ \\
\hline Number of Observations & 4710 & 2674 & 959 & 795 \\
\hline Adjusted R Squared & 0.26 & 0.25 & 0.28 & 0.27 \\
\hline Std Error of Regression & 0.43 & 0.26 & 0.29 & 0.27 \\
\hline Sum of Squared Residuals & 830.37 & 168.96 & 76.43 & 55.19 \\
\hline \multicolumn{5}{|c|}{$\begin{array}{l}\text { Notes: } \\
{ }^{1}: \text { Sample period from } 1990 \text { to } 2008 . \\
\text { t-statistics are provided beneath the coefficient estimates in smaller italic font. } \\
\text { One-sided statistical signifincance at } 1,5,10 \text { and } 20 \text { percent level are indicated by } * * *, * * *, * * \text { and }{ }^{*} \text {, respectively. }\end{array}$} \\
\hline
\end{tabular}




\section{Potential for Bias in Results}

The equilibrium value of the real exchange rate in this paper is based on econometric estimates of the long-run relationship based on macroeconomic fundamentals. As in any econometric analysis, because the results are prone to biases, the equilibrium relationship based on the estimation results should be treated with caution.

Second, the equilibrium values estimated with all four methodologies implicitly assume that the macroeconomic fundamentals of a country are sustainable. For instance, in the macroeconomic balance approach, the equilibrium level of the current account balance may not be sustainable if a country's fiscal balance is not sustainable in the medium term.

Third, import and export elasticity estimates used in this paper are not country specific. Due to data limitations, in this paper, we calibrated elasticity of imports and exports with respect to the real exchange rate to the findings presented in Isard and Faruqee (1998). If these elasticities do not reflect the country-specifics or are out-dated then the exchange rate deviation to close the gap between the underlying and the norm current account balances may get over- or under-magnified depending on whether the calibrated elasticities are smaller or larger than the true elasticities.

Last, an exchange rate under- or overvaluation does not necessarily indicate that the exchange rate needs to adjust. There might be cases, where the exchange rate under- or overvaluation is due to structural or macroeconomic challenges that a country is facing. In such cases, the country authorities may choose to address these challenges rather than adjusting the exchange rate to eliminate external imbalances.

\section{CONCLUSION}

This paper analyzes the real exchange rate for sub-Saharan Africa with respect to its equilibrium value. We use four methodologies to estimate the equilibrium level: the macroeconomic balance, equilibrium real exchange rate, external sustainability and purchasing power parity approaches. Based on all four methodologies and the samples used, our results indicate that the sub-Saharan African economies have different dynamics than do advanced and other LMIC. 


\section{REFERENCE}

Chinn, M. D., and E. S. Prasad, 2003, "Medium-Term Determinants of Current Accounts in Industrial and Developing Countries: An Empirical Exploration," Journal of International Economics, Vol. 59, No. 1, pp. 47-76.

Christiansen, L., A. Prati, Luca Antonio Ricci, and T. Tressel, 2009, "External Balance in Low-Income Countries,” IMF Working Paper No. 09/221 (Washington: International Monetary Fund).

Deléchat, C., and M. Gaertner, 2008, "Exchange Rate Assessment in a Resource-Dependent Economy: The Case of Botswana," IMF Working Paper No. 08/83 (Washington: International Monetary Fund).

International Monetary Fund, 2009a, World Economic Outlook, October (Washington). , 2009b, Namibia: Selected Issues Paper, IMF Country Report No. 08/132 (Washington).

,2009c, Namibia: 2008 Article IV Consultation_-Staff Report, IMF Country Report No. 09/136 (Washington).

, 2008a, Botswana: Selected Issues Paper, IMF Country Report No. 08/57 (Washington).

, 2008b, Botswana: 2007 Article IV Consultation-Staff Report, IMF Country Report No. 08/58 (Washington).

, 2008c, Kingdom of Lesotho: Selected Issues and Statistical Appendix, IMF Country Report No. 08/135 (Washington).

, 2008d, Kingdom of Lesotho: 2007 Article IV Consultation-Staff Report, IMF Country Report No. 08/136 (Washington).

, 2008e, Kingdom of Swaziland: Selected Issues and Statistical Appendix, IMF Country Report No. 08/355 (Washington).

, 2008f, Kingdom of Swaziland: 2008 Article IV Consultation—Staff Report, IMF Country Report No. 08/356 (Washington).

, 2006, Methodology for CGER Assessments (Washington).

Isard, Peter, and Hamid Faruqee, eds., 1998, Exchange Rate Assessment: Extensions of the Macroeconomic Balance Approach, IMF Occasional Paper No. 167 (Washington: International Monetary Fund). 
Isard, P., 2007, "Equilibrium Exchange Rates: Assessment Methodologies," IMF Working Paper No. 296 (Washington: International Monetary Fund).

Jbili, A., and V. Kramarenko, 2003a, Choosing Exchange Regimes in the Middle East and North Africa (Washington: International Monetary Fund). ,2003b, "Should MENA Countries Float or Peg?" Finance \& Development, Vol. 40, No. 1.

Lane, P. R., and G. Milesi-Ferretti, 2001a, "The External Wealth of Nations: Measures of Foreign Assets and Liabilities for Industrial and Developing Countries," Journal of International Economics, Vol. 55, pp. 263-94. ,2001, “Long-Term Capital Movements,” NBER Working Papers 8366 (Cambridge, MA: National Bureau of Economic Research, Inc.).

Lee, J., G. Milesi-Ferretti, J. Ostry, A. Prati, and L. Ricci, 2008, "Exchange Rrate Assessments: CGER Methodologies," IMF Occasional Paper 261 (Washington: International Monetary Fund).

Miyajima, K., 2007, “What Do We Know About Namibia’s Competitiveness?” IMF Working Paper No. 07/191 (Washington: International Monetary Fund).

Mongardini, J., and B. Rayner, 2009, "Grants, Remittances, and the Equilibrium Real Exchange Rate in Sub-Saharan African Countries," IMF Working Paper No. 09/75 (Washington: International Monetary Fund).

Sharma, K., 2009, “The Impact of Remittances on Economic Insecurity,” DESA Working Paper No. 78 (New York: UN Department of Economic and Social Affairs)

Uppsala Conflict Data Program (date of retrieval: June 2009) UCDP database: www.ucdp.uu.se/database, Uppsala University.

Vitek, F., 2009, Exchange Rate Assessment Tools for Advanced, Emerging, and Developing Economies (Washington: International Monetary Fund). 


\section{Appendix I. Unit Root Test Results}

\section{Table 9. Panel Unit Root Test Result for Real Exchange Rate}

Panel unit root test: Summary

Series: Logarithm of REER

Sample: 19732008

Exogenous variables: Individual effects

User specified maximum lags

Automatic selection of lags based on AIC: 0 to 4

Newey-West bandwidth selection using Bartlett kernel

\begin{tabular}{|c|c|c|c|c|}
\hline Method & Statistic & Prob.** & $\begin{array}{c}\text { Cross- } \\
\text { sections }\end{array}$ & Obs \\
\hline \multicolumn{5}{|c|}{ Null: Unit root (assumes common unit root process) } \\
\hline Levin, Lin \& Chu t* & -10.8863 & 0.0000 & 178 & 4328 \\
\hline \multicolumn{5}{|c|}{ Null: Unit root (assumes individual unit root process) } \\
\hline Im, Pesaran and Shin W-stat & -9.55476 & 0.0000 & 178 & 4328 \\
\hline ADF - Fisher Chi-square & 693.021 & 0.0000 & 178 & 4328 \\
\hline PP - Fisher Chi-square & 561.375 & 0.0000 & 178 & 4532 \\
\hline
\end{tabular}

** Probabilities for Fisher tests are computed using an asymptotic Chi -square distribution. All other tests assume asymptotic normality.

\section{Table 10. Panel Unit Root Test Results for Current Account Balance}

Panel unit root test: Summary

Series: CAB-to-GDP

Sample: 19732008

Exogenous variables: Individual effects

User specified maximum lags

Automatic selection of lags based on AIC: 0 to 4

Newey-West bandwidth selection using Bartlett kernel

\begin{tabular}{|c|c|c|c|c|}
\hline Method & Statistic & Prob. ${ }^{* *}$ & $\begin{array}{c}\text { Cross- } \\
\text { sections }\end{array}$ & Obs \\
\hline \multicolumn{5}{|c|}{ Null: Unit root (assumes common unit root process) } \\
\hline Levin, Lin \& Chu t* & -9.59881 & 0.0000 & 176 & 5777 \\
\hline \multicolumn{5}{|c|}{ Null: Unit root (assumes individual unit root process) } \\
\hline Im, Pesaran and Shin W-stat & -12.8458 & 0.0000 & 176 & 5777 \\
\hline ADF - Fisher Chi-square & 845.572 & 0.0000 & 176 & 5777 \\
\hline PP - Fisher Chi-square & 867.291 & 0.0000 & 176 & 5949 \\
\hline
\end{tabular}

** Probabilities for Fisher tests are computed using an asymptotic Chi -square distribution. All other tests assume asymptotic normality. 
Table 11. Panel Unit Root Test Result for Relative Income per Capita

Panel unit root test: Summary

Series: Relative Income-per-Capita (with respect to weighted average of trading partners)

Sample: 19732008

Exogenous variables: Individual effects

User specified maximum lags

Automatic selection of lags based on AIC: 0 to 4

Newey-West bandwidth selection using Bartlett kernel

\begin{tabular}{|c|c|c|c|c|}
\hline Method & Statistic & Prob. ${ }^{* *}$ & $\begin{array}{l}\text { Cross- } \\
\text { sections }\end{array}$ & Obs \\
\hline \multicolumn{5}{|c|}{ Null: Unit root (assumes common unit root process) } \\
\hline Levin, Lin \& Chu $t^{*}$ & -5.46507 & 0.0000 & 174 & 5478 \\
\hline \multicolumn{5}{|c|}{ Null: Unit root (assumes individual unit root process) } \\
\hline Im, Pesaran and Shin W-stat & 0.82176 & 0.7944 & 174 & 5478 \\
\hline ADF - Fisher Chi-square & 401.867 & 0.0244 & 174 & 5478 \\
\hline PP - Fisher Chi-square & 388.555 & 0.0660 & 174 & 5662 \\
\hline
\end{tabular}

** Probabilities for Fisher tests are computed using an asymptotic Chi -square distribution. All other tests assume asymptotic normality.

\section{Table 12. Panel Unit Root Test Results for Relative Fiscal Balance}

Panel unit root test: Summary

Series: Relative Fiscal Balance to GDP (with respect to weighted average of trading partners)

Sample: 19732008

Exogenous variables: Individual effects

User specified maximum lags

Automatic selection of lags based on AIC: 0 to 4

Newey-West bandwidth selection using Bartlett kernel

\begin{tabular}{|c|c|c|c|c|}
\hline Method & Statistic & Prob.** & $\begin{array}{l}\text { Cross- } \\
\text { sections }\end{array}$ & Obs \\
\hline \multicolumn{5}{|c|}{ Null: Unit root (assumes common unit root process) } \\
\hline Levin, Lin \& Chu t* & -9.38103 & 0.0000 & 150 & 2821 \\
\hline \multicolumn{5}{|c|}{ Null: Unit root (assumes individual unit root process) } \\
\hline Im, Pesaran and Shin W-stat & -10.8302 & 0.0000 & 150 & 2821 \\
\hline ADF - Fisher Chi-square & 681.891 & 0.0000 & 150 & 2821 \\
\hline PP - Fisher Chi-square & 694.753 & 0.0000 & 150 & 3007 \\
\hline
\end{tabular}

** Probabilities for Fisher tests are computed using an asymptotic Chi -square distribution. All other tests assume asymptotic normality. 
Table 13. Panel Unit Root Test Result for Relative Population Growth

Panel unit root test: Summary

Series: Relative Population Growth (with respect to

weighted average of trading partners)

Sample: 19732008

Exogenous variables: Individual effects

User specified maximum lags

Automatic selection of lags based on AIC: 0 to 4

Newey-West bandwidth selection using Bartlett kernel

\begin{tabular}{lcccc}
\hline \hline & & & \\
Method & Statistic & Prob. ${ }^{* *}$ & sections & Obs \\
\hline Null: Unit root (assumes common unit root process) & & & \\
\hline Levin, Lin \& Chu t* & -29.0869 & 0.0000 & 174 & 5378 \\
& & & & \\
Null: Unit root (assumes individual unit root process) & & & \\
\hline Im, Pesaran and Shin W-stat & -35.0818 & 0.0000 & 174 & 5378 \\
ADF - Fisher Chi-square & 1928.58 & 0.0000 & 174 & 5378 \\
PP - Fisher Chi-square & 2320.50 & 0.0000 & 174 & 5537 \\
\hline \hline
\end{tabular}

** Probabilities for Fisher tests are computed using an asymptotic Chi -square distribution. All other tests assume asymptotic normality.

\section{Table 14. Panel Unit Root Test Result for Relative Economic Growth}

Panel unit root test: Summary

Series: Relative PPP per Capita Growth (with respect to weighted average of trading partners)

Sample: 19732008

Exogenous variables: Individual effects

User specified maximum lags

Automatic selection of lags based on AIC: 0 to 4

Newey-West bandwidth selection using Bartlett kernel

\begin{tabular}{|c|c|c|c|c|}
\hline Method & Statistic & Prob.** & $\begin{array}{l}\text { Cross- } \\
\text { sections }\end{array}$ & Obs \\
\hline \multicolumn{5}{|c|}{ Null: Unit root (assumes common unit root process) } \\
\hline Levin, Lin \& Chu $\mathrm{t}^{*}$ & -1.09253 & 0.1373 & 165 & 3649 \\
\hline \multicolumn{5}{|c|}{ Null: Unit root (assumes individual unit root process) } \\
\hline Im, Pesaran and Shin W-stat & -7.62501 & 0.0000 & 165 & 3649 \\
\hline ADF - Fisher Chi-square & 603.240 & 0.0000 & 165 & 3649 \\
\hline PP - Fisher Chi-square & 642.903 & 0.0000 & 165 & 3839 \\
\hline
\end{tabular}

** Probabilities for Fisher tests are computed using an asymptotic Chi -square distribution. All other tests assume asymptotic normality. 
Table 15. Panel Unit Root Test Result for Initial Net Foreign Assets

Panel unit root test: Summary

Series: Net Foreign Assets to GDP

Sample: 19732008

Exogenous variables: Individual effects

User specified maximum lags

Automatic selection of lags based on AIC: 0 to 4

Newey-West bandwidth selection using Bartlett kernel

\begin{tabular}{|c|c|c|c|c|}
\hline Method & Statistic & Prob.** & $\begin{array}{l}\text { Cross- } \\
\text { sections }\end{array}$ & Obs \\
\hline \multicolumn{5}{|c|}{ Null: Unit root (assumes common unit root process) } \\
\hline Levin, Lin \& Chu $\mathrm{t}^{*}$ & -37.7314 & 0.0000 & 53 & 852 \\
\hline \multicolumn{5}{|c|}{ Null: Unit root (assumes individual unit root process) } \\
\hline Im, Pesaran and Shin W-stat & -8.29799 & 0.0000 & 53 & 852 \\
\hline ADF - Fisher Chi-square & 146.426 & 0.0057 & 53 & 852 \\
\hline PP - Fisher Chi-square & 93.2637 & 0.8068 & 53 & 943 \\
\hline
\end{tabular}

** Probabilities for Fisher tests are computed using an asymptotic Chi -square distribution. All other tests assume asymptotic normality.

\section{Table 16. Panel Unit Root Test Result for Terms of Trade}

Panel unit root test: Summary

Series: Logarithm of Terms of Trade

Sample: 19732008

Exogenous variables: Individual effects

User specified maximum lags

Automatic selection of lags based on AIC: 0 to 4

Newey-West bandwidth selection using Bartlett kernel

\begin{tabular}{lcccc}
\hline \hline & & & Cross- & \\
Method & Statistic & Prob.** & sections & Obs \\
\hline Null: Unit root (assumes common unit root process) & & & \\
\hline Levin, Lin \& Chu t* & -3.29297 & 0.0005 & 167 & 5638 \\
& & & \\
Null: Unit root (assumes individual unit root process) & & & \\
\hline Im, Pesaran and Shin W-stat & -5.29839 & 0.0000 & 167 & 5638 \\
ADF - Fisher Chi-square & 538.842 & 0.0000 & 167 & 5638 \\
PP - Fisher Chi-square & 623.420 & 0.0000 & 167 & 5776 \\
\hline \hline
\end{tabular}

** Probabilities for Fisher tests are computed using an asymptotic Chi -square distribution. All other tests assume asymptotic normality. 


\section{Table 17. Panel Unit Root Test Result for Oil Trade Balance}

Panel unit root test: Summary

Series: Trade Balance on Oil to GDP

Sample: 19732008

Exogenous variables: Individual effects

User specified maximum lags

Automatic selection of lags based on AIC: 0 to 4

Newey-West bandwidth selection using Bartlett kernel

\begin{tabular}{|c|c|c|c|c|}
\hline Method & Statistic & Prob.** & $\begin{array}{l}\text { Cross- } \\
\text { sections }\end{array}$ & Obs \\
\hline \multicolumn{5}{|c|}{ Null: Unit root (assumes common unit root process) } \\
\hline Levin, Lin \& Chu t* & -6.57864 & 0.0000 & 168 & 5477 \\
\hline \multicolumn{5}{|c|}{ Null: Unit root (assumes individual unit root process) } \\
\hline Im, Pesaran and Shin W-stat & -4.10258 & 0.0000 & 168 & 5477 \\
\hline ADF - Fisher Chi-square & 494.272 & 0.0000 & 168 & 5477 \\
\hline PP - Fisher Chi-square & 518.009 & 0.0000 & 168 & 5608 \\
\hline
\end{tabular}

** Probabilities for Fisher tests are computed using an asymptotic Chi -square distribution. All other tests assume asymptotic normality.

\section{Table 18. Panel Unit Root Test Result for Relative Dependency Ratio}

Panel unit root test: Summary

Series: Relative Old Age Dependency (with respect to

weighted average of trading partners)

Sample: 19732008

Exogenous variables: Individual effects

User specified maximum lags

Automatic selection of lags based on AIC: 0 to 4

Newey-West bandwidth selection using Bartlett kernel

\begin{tabular}{lcccc}
\hline \hline & \multicolumn{3}{c}{ Cross- } \\
Method & Statistic & Prob.* & sections & Obs \\
\hline Null: Unit root (assumes common unit root process) & & \\
\hline Levin, Lin \& Chu t* & -9.99986 & 0.0000 & 181 & 5458 \\
& & & \\
Null: Unit root (assumes individual unit root process) & & 181 & 5458 \\
\hline Im, Pesaran and Shin W-stat & -2.04896 & 0.0202 & 181 & 5458 \\
ADF - Fisher Chi-square & 500.833 & 0.0000 & 181 & 5865 \\
PP - Fisher Chi-square & 145.120 & 1.0000 & 181 \\
\hline \hline
\end{tabular}

** Probabilities for Fisher tests are computed using an asymptotic Chi -square distribution. All other tests assume asymptotic normality. 


\section{Table 19. Panel Unit Root Test Result for Aid}

Panel unit root test: Summary

Series: Aid to GDP

Sample: 19732008

Exogenous variables: Individual effects

User specified maximum lags

Automatic selection of lags based on AIC: 0 to 4

Newey-West bandwidth selection using Bartlett kernel

\begin{tabular}{lcccc}
\hline \hline & & & \\
Method & Statistic & Prob. ${ }^{* *}$ & $\begin{array}{c}\text { Cross- } \\
\text { sections }\end{array}$ & Obs \\
\hline Null: Unit root (assumes common unit root process) & & \\
\hline Levin, Lin \& Chu t* & -76.1424 & 0.0000 & 150 & 4479 \\
& & & \\
Null: Unit root (assumes individual unit root process) & & \\
\hline Im, Pesaran and Shin W-stat & -20.5430 & 0.0000 & 150 & 4479 \\
ADF - Fisher Chi-square & 746.075 & 0.0000 & 150 & 4479 \\
PP - Fisher Chi-square & 828.990 & 0.0000 & 150 & 4626 \\
\hline \hline
\end{tabular}

** Probabilities for Fisher tests are computed using an asymptotic Chi -square distribution. All other tests assume asymptotic normality.

\section{Table 20. Panel Unit Root Test Result for Remittance}

Panel unit root test: Summary

Series: Remittances to GDP

Sample: 19732008

Exogenous variables: Individual effects

User specified maximum lags

Automatic selection of lags based on AIC: 0 to 4

Newey-West bandwidth selection using Bartlett kernel

\begin{tabular}{|c|c|c|c|c|}
\hline Method & Statistic & Prob. ${ }^{* *}$ & $\begin{array}{c}\text { Cross- } \\
\text { sections }\end{array}$ & Obs \\
\hline \multicolumn{5}{|c|}{ Null: Unit root (assumes common unit root process) } \\
\hline Levin, Lin \& Chu t* & -6.64636 & 0.0000 & 102 & 2275 \\
\hline \multicolumn{5}{|c|}{ Null: Unit root (assumes individual unit root process) } \\
\hline Im, Pesaran and Shin W-stat & 0.28604 & 0.6126 & 102 & 2275 \\
\hline ADF - Fisher Chi-square & 308.606 & 0.0000 & 102 & 2275 \\
\hline PP - Fisher Chi-square & 286.332 & 0.0001 & 102 & 2420 \\
\hline
\end{tabular}

** Probabilities for Fisher tests are computed using an asymptotic Chi -square distribution. All other tests assume asymptotic normality. 